\title{
Impact of the AT(2) Receptor Agonist C21 on Blood Pressure and Beyond
}

Citation for published version (APA):

Foulquier, S., Steckelings, U. M., \& Unger, T. (2012). Impact of the AT(2) Receptor Agonist C21 on Blood Pressure and Beyond. Current Hypertension Reports, 14(5), 403-409. https://doi.org/10.1007/s11906-0120291-6

Document status and date:

Published: 01/10/2012

DOI:

10.1007/s11906-012-0291-6

Document Version:

Publisher's PDF, also known as Version of record

Document license:

Taverne

Please check the document version of this publication:

- A submitted manuscript is the version of the article upon submission and before peer-review. There can be important differences between the submitted version and the official published version of record.

People interested in the research are advised to contact the author for the final version of the publication, or visit the DOI to the publisher's website.

- The final author version and the galley proof are versions of the publication after peer review.

- The final published version features the final layout of the paper including the volume, issue and page numbers.

Link to publication

\footnotetext{
General rights rights.

- You may freely distribute the URL identifying the publication in the public portal. please follow below link for the End User Agreement:

www.umlib.nl/taverne-license

Take down policy

If you believe that this document breaches copyright please contact us at:

repository@maastrichtuniversity.nl

providing details and we will investigate your claim.
}

Copyright and moral rights for the publications made accessible in the public portal are retained by the authors and/or other copyright owners and it is a condition of accessing publications that users recognise and abide by the legal requirements associated with these

- Users may download and print one copy of any publication from the public portal for the purpose of private study or research.

- You may not further distribute the material or use it for any profit-making activity or commercial gain

If the publication is distributed under the terms of Article $25 \mathrm{fa}$ of the Dutch Copyright Act, indicated by the "Taverne" license above, 


\title{
Impact of the $\mathrm{AT}_{2}$ Receptor Agonist C21 on Blood Pressure and Beyond
}

\author{
Sébastien Foulquier • U. Muscha Steckelings • \\ Thomas Unger
}

Published online: 27 July 2012

(C) Springer Science+Business Media, LLC 2012

\begin{abstract}
It is now widely accepted that the angiotensin $\mathrm{AT}_{2}$ receptor $\left(\mathrm{AT}_{2} \mathrm{R}\right)$ plays an important protective role during pathophysiologic conditions, acting as a repair system. The development of the first selective nonpeptide $\mathrm{AT}_{2} \mathrm{R}$ agonist $\mathrm{C} 21$ accelerated our understanding of $\mathrm{AT}_{2} \mathrm{R}$-mediated protective signaling and actions. This article reviews the impact of $\mathrm{C} 21$ on blood pressure in normotensive and hypertensive animal models. Although $\mathrm{C} 21$ does not act as a classical antihypertensive drug, it could be useful in preventing hypertension-induced vascular and other end organ damages via anti-apoptotic, anti-fibrotic and anti-inflammatory actions. In particular, a strong body of evidence started to emerge around its anti-inflammatory feature. This property should be further investigated for potential clinical indications in cardiovascular diseases and beyond.
\end{abstract}

Keywords Hypertension - Blood pressure - Angiotensin . $\mathrm{AT}_{2} \mathrm{R} \cdot$ Renin-angiotensin system $\cdot \mathrm{RAS} \cdot$ Compound 21 . $\mathrm{C} 21 \cdot$ Inflammation $\cdot$ Antihypertensive drug therapy

S. Foulquier $\cdot$ T. Unger

Cardiovascular Research Institute Maastricht (CARIM),

Maastricht University,

Maastricht, The Netherlands

S. Foulquier

e-mail: s.foulquier@maastrichtuniversity.nl

U. M. Steckelings

Center for Cardiovascular Research,

Charité -Universitätsmedizin Berlin,

Hessische Str. 3-4,

10115 Berlin, Germany

e-mail: ulrike.steckelings@charite.de

S. Foulquier $\cdot$ T. Unger $(\bowtie)$

CARIM - School for Cardiovascular Diseases,

Maastricht University,

Universiteitssingel 50, PO Box 616, Maastricht 6200 MD,

The Netherlands

e-mail: t.unger@maastrichtuniversity.nl

\section{Introduction}

The renin angiotensin system (RAS) plays a key role in blood pressure regulation. Its actions have been described as mostly dependent on stimulation of the Ang II receptor type $1\left(\mathrm{AT}_{1} \mathrm{R}\right)$. The development of $\mathrm{AT}_{1} \mathrm{R}$ blockers (ARB) and other receptor subtype-specific ligands in the 1990s revealed a second Ang II receptor subtype, the angiotensin $\mathrm{AT}_{2}$ receptor $\left(\mathrm{AT}_{2} \mathrm{R}\right)$ [1]. Since this discovery, several research groups have contributed to improving our understanding of this 'enigmatic' receptor [2]. It is now widely recognized that the $\mathrm{AT}_{2} \mathrm{R}$ receptor exerts actions opposing those of the $\mathrm{AT}_{1} \mathrm{R}$, such as vasodilation, anti-proliferation, cell differentiation and anti-inflammation [3-7]. Although all mechanisms are still not fully deciphered, a picture of $\mathrm{AT}_{2} \mathrm{R}$ signaling has emerged with three major transduction mechanisms: (1) activation of the NO/cGMP pathway, (2) activation of a series of protein phosphatases and (3) activation of phospholipase A2 inducing the release of arachidonic acid [8]. All or some of these signaling cascades seem to be initiated by various proteins binding to the $\mathrm{C}$ terminal end of the $\mathrm{AT}_{2}-\mathrm{R}$ such as the " $\mathrm{AT}_{2}-\mathrm{R}$ binding proteins" (ATIP or ATBP, $[9,10 \bullet]$ ), the homeodomain enhancer protein and Zfhep, and the transcription factor PLZF (promyelocytic leukemia zinc finger, [11, 12]). These pathways have to be further investigated, especially with regard to their importance in anti- or pro-proliferative and cellular differentiation actions of the $\mathrm{AT}_{2} \mathrm{R}$ (see $[6,13 \cdot]$ for review of $\mathrm{AT}_{2} \mathrm{R}$ signaling).

The $\mathrm{AT}_{1} \mathrm{R}$-opposed actions of the $\mathrm{AT}_{2} \mathrm{R}$ are not only determined by specific signaling pathways but also by the levels of $\mathrm{AT}_{2} \mathrm{R}$ expression in a given tissue. Early evidence for this was provided by Gohlke et al. in 1998 [14] and Pees et al. [15]. These authors demonstrated that $\mathrm{AT}_{2} \mathrm{R}$ stimulation in the aorta of adult SHR-SP was responsible for activation of the bradykinin/NO/GMPc pathway [14]. In contrast, they did not find any evidence for such 
$\mathrm{AT}_{2} \mathrm{R}$-mediated $\mathrm{NO}$ production in the vascular wall of WKY rats [15]. What seems to be a discordance between these two rat strains can indeed be explained by a significantly higher expression level of $\mathrm{AT}_{2} \mathrm{R}$ in SHR compared to WKY [16]. In fact, the $A T_{1} R / A T_{2} R$ ratio seems to be modified according to a given pathophysiologic state $[17,18]$. In particular, $\mathrm{AT}_{2} \mathrm{R}$ expression is upregulated in tissue injury $[19,20]$, suggesting this could constitute a protective system during pathophysiologic processes.

In this context, exploiting the therapeutic potential of the 'protective arm' of the RAS, to which the $\mathrm{AT}_{2} \mathrm{R}$ as well as ACE2 and the Ang1-7/Mas receptor system belong [21], became a focus of interest with respect to drug development. The $\mathrm{AT}_{2} \mathrm{R}$ thus became a potential therapeutic target, and synthesis of compounds stimulating the $\mathrm{AT}_{2} \mathrm{R}$ was initiated. Compound 21 (C21) evolved from these efforts as the first selective nonpeptide $\mathrm{AT}_{2} \mathrm{R}$ agonist [22].

Before the advent of $\mathrm{C} 21$, research on $\mathrm{AT}_{2} \mathrm{R}$ functions was conducted either via indirect stimulation with Ang II in the presence of an $\mathrm{ARB}$, via blockade of $\mathrm{AT}_{2} \mathrm{R}$ function with an $\mathrm{AT}_{2} \mathrm{R}$ antagonist or by elimination of $\mathrm{AT}_{2} \mathrm{R}$ function using $\mathrm{AT}_{2} \mathrm{R}$ knockout animals. The only early compound to directly stimulate the $\mathrm{AT}_{2} \mathrm{R}$ was the peptide CGP42112A. Unfortunately, due to its peptidic nature, its use in vivo was limited. Moreover, CGP42112A also features antagonistic properties at low concentrations [4]. The synthetic $\mathrm{AT}_{2} \mathrm{R}$ agonist, $\mathrm{C} 21$, thus constitutes the first pharmacokinetically unproblematic tool for the direct study of $\mathrm{AT}_{2} \mathrm{R}$ functions and the first $\mathrm{AT}_{2} \mathrm{R}$ agonist with drug-like properties. As a result, several experimental studies using $\mathrm{C} 21$ have been performed. With the background provided by preclinical studies since 2004 [22] and a currently ongoing toxicological program, it is anticipated that $\mathrm{C} 21$ is soon going to enter a clinical phase I study. In this article, we will summarize the important properties of $\mathrm{C} 21$ identified up to now.

\section{Compound 21 and Blood Pressure}

Since stimulation of $\mathrm{AT}_{2} \mathrm{R}$ induces vasodilation in isolated vessels and production of $\mathrm{NO}$, one might reasonably think that administration of $\mathrm{C} 21$ would generate a decrease in blood pressure (BP). However, as summarized in Table 1, stimulation of $\mathrm{AT}_{2} \mathrm{R}$ in vivo does not yield a hypotensive effect - at least not acutely.

In fact, $\mathrm{C} 21$ alone did not decrease blood pressure when administered in normotensive animals [22, 23••, 24, 25]. Moreover, in animal models of hypertension, regardless of the type of hypertension (genetic or induced), C21 did not provide any antihypertensive action either $[23 \bullet \bullet, 26 \bullet, 27 \bullet$, 28., 29]. A decrease in BP was only described in the original publication about $\mathrm{C} 21$ synthesis and design [22]. In this study, a decrease in BP was observed following an acute i.v. infusion of $\mathrm{C} 21$ in SHR, but this was observed in anesthetized animals in which anesthesia may have hampered baroreflex control of BP. Thus, current evidence does not reveal any acute antihypertensive action of C21 in conscious animals, despite the diversity of treatment dosage, duration and route of administration tested (Table 1).

However, a potential antihypertensive effect of $\mathrm{C} 21$ alone may not be easily detectable in vivo because of a predominant $\mathrm{AT}_{1} \mathrm{R}$-dependent angiotensinergic tone. Thus, in order to observe effects resulting from $\mathrm{AT}_{2} \mathrm{R}$ stimulation, it may be necessary to block $A_{1} R$. In fact, when combined with a low-dose ARB that does not modify BP, C21 exerted an antihypertensive action [23••]. This is in agreement with previous results obtained with CGP42112A [30-32]. When $\mathrm{C} 21$ was combined with a high dose of an $\mathrm{ARB}$, which induces an antihypertensive effect, no additive effect of $\mathrm{C} 21$ on BP was observed [27•, 28•].

Although stimulation of $\mathrm{AT}_{2} \mathrm{R}$ with the $\mathrm{AT}_{2}$ agonist $\mathrm{C} 21$ does not engender direct, acute antihypertensive effects, a secondary reduction of BP may occur because of favorable effects of chronic $\mathrm{C} 21$ administration on vascular remodeling and kidney function. A trend towards a reduction of BP has indeed been observed in models of renal hypertension [26•], L-NAME induced hypertension [28•] and diabetic SHR-SP (unpublished observation), but these effects did not reach statistical significance.

Since the decrease in $\mathrm{BP}$ by $\mathrm{AT}_{2} \mathrm{R}$-stimulation is only minor or in some studies not detectable at all, favorable effects of $\mathrm{C} 21$ in models of hypertensive end organ damage can be regarded as mainly or entirely BP independent. For example, Rehman et al. highlighted a reduction in vascular stiffness by $\mathrm{C} 21$ treatment in the aorta but also in mesenteric resistance arteries from hypertensive rats (SHR-SP) independently of any BP reduction [27•]. Moreover, our group has recently demonstrated that $\mathrm{C} 21$ treatment prevents the development of hypertension-induced aortic remodeling and accelerated pulse-wave velocity in L-NAME hypertensive rats without significantly changing $\mathrm{BP}$ [28•]. The C21induced reduction of stiffness of mesenteric resistance arteries observed in the study by Rehman et al. as well as attenuated aortic stiffness in our study could in both cases be explained by a decrease in extracellular matrix components, collagen content and fibronectin. This may limit the increase in vascular resistance and, subsequently, the progression of hypertension as well as end-organ damage concomitant with chronic hypertension. Furthermore, at the kidney level, $\mathrm{AT}_{2} \mathrm{R}$ stimulation with $\mathrm{C} 21$ produced vasodilatory and natriuretic effects and may therefore also improve renal function [24]. Despite the absence of direct antihypertensive action, C21 could thus be a useful additional tool in the long-term management of hypertension. 
Table 1 Effect of $\mathrm{C} 21$ on blood pressure. Effect of $\mathrm{C} 21$ alone, associated with a high antihypertensive dose or a low non-antihypertensive dose of angiotensin receptor blocker (ARB) on blood pressure of normotensive, hypertensive or other pathologic animal models. C21 dosage, route and treatment duration are detailed

\begin{tabular}{|c|c|c|c|c|c|c|}
\hline Animal model & C21 dosage & Route & Duration & $\begin{array}{l}\text { Anesthetized } \\
\text { animal }\end{array}$ & $\begin{array}{l}\text { Effect } \\
\text { on BP }\end{array}$ & Ref. \\
\hline \multicolumn{7}{|l|}{ C21 alone } \\
\hline S-D & $0.05 \mathrm{mg} / \mathrm{kg}$ & i.v. & acute & Yes & No & [22] \\
\hline SHR & $0.05 \mathrm{mg} / \mathrm{kg}$ & i.v. & acute & Yes & $\downarrow$ & [22] \\
\hline WKY or SHR, 16-18 w.o. & 50 to $1000 \mathrm{ng} / \mathrm{kg} / \mathrm{min}$ & i.v. & $4 \mathrm{~h}$ & No & No & {$[23 \bullet \bullet]$} \\
\hline S-D, 11-12 w.o. & 100 to $300 \mathrm{ng} / \mathrm{kg} / \mathrm{min}$ & i.v. & acute & Yes & No & {$[24]$} \\
\hline $\mathrm{S}-\mathrm{D}, 2 \mathrm{~K} 1 \mathrm{C}$ & $0.3 \mathrm{mg} / \mathrm{kg} /$ day & i.p. & 4 days & No & No & {$[26 \bullet]$} \\
\hline Wistar rats with myocardial infarction & $0.01,0.03$, or $0.3 \mathrm{mg} / \mathrm{kg}$ & i.p. & 6 days & Yes & No & {$[33 \bullet \bullet]$} \\
\hline C57BL/6 mice, 10-12 w.o. & 1,3 , and $10 \mathrm{mg} / \mathrm{kg} /$ day & i.p. & 2 weeks & No & No & [25] \\
\hline SHR-SP, 6 w.o. & $1 \mathrm{mg} / \mathrm{kg} /$ day & per os & 6 weeks & No & No & {$[27 \bullet]$} \\
\hline Wistar, 10 w.o. + L-NAME & $0.3 \mathrm{mg} / \mathrm{kg} / \mathrm{day}$ & per os & 6 weeks & No & No & {$[28 \bullet]$} \\
\hline SHR-SP, $4-5$ w.o. $+1 \% \mathrm{NaCl}$ & $0.75,5$ or $10 \mathrm{mg} / \mathrm{kg} /$ day & per os & until death & No & No & [29] \\
\hline \multicolumn{7}{|l|}{ C21 associated with a high-dose ARB } \\
\hline SHR-SP, 6 w.o. + losartan $(10 \mathrm{mg} / \mathrm{kg} /$ day per os $)$ & $1 \mathrm{mg} / \mathrm{kg} /$ day & per os & 6 weeks & No & No & {$[27 \cdot]$} \\
\hline $\begin{array}{l}\text { Wistar, } 10 \text { w.o. + L-NAME + olmesartan } \\
\text { medoxomil }(10 \mathrm{mg} / \mathrm{kg} / \text { day per os })\end{array}$ & $0.3 \mathrm{mg} / \mathrm{kg} /$ day & per os & 6 weeks & No & No & {$[28 \bullet]$} \\
\hline \multicolumn{7}{|l|}{$\mathrm{C} 21$ associated with a low-dose ARB } \\
\hline SHR, $16-18$ w.o. + candesartan $(0.1 \mathrm{mg} / \mathrm{kg}$ bolus i.v. $)$ & $50 \mathrm{ng} / \mathrm{kg} / \mathrm{min}$ & i.v. & $4 \mathrm{~h}$ & No & $\downarrow$ & {$[23 \bullet \bullet]$} \\
\hline
\end{tabular}

\section{Compound 21 and Anti-inflammation}

Recent investigations, reviewed in the following, have revealed other beneficial effects beyond those for hypertension provided by $\mathrm{C} 21$.

In a model of myocardial infarction (MI) performed in Wistar rats, treatment with $\mathrm{C} 21$ improved cardiac function and decreased scar size after 7 days of treatment [33••]. The underlying mechanisms may include the strong antiinflammatory effects of C21. Several inflammatory markers, increased following MI, were indeed lowered by $\mathrm{C} 21$, such as plasma monocyte chemoattractant protein-1 (MCP-1) and several proinflammatory cytokines. Moreover, in the periinfarct zone, $\mathrm{C} 21$ attenuated the rise of apoptosis markers. These effects were blocked by the $\mathrm{AT}_{2} \mathrm{R}$ antagonist $\mathrm{PD} 123319$, supporting that specific $\mathrm{AT}_{2} \mathrm{R}$ stimulation by $\mathrm{C} 21$ exerted anti-inflammatory and anti-apoptotic actions in the context of MI.

In contrast, in a recent study with MI induced in mice, the authors did not observe a reduction of left ventricular remodeling following $\mathrm{AT}_{2} \mathrm{R}$ stimulation with $\mathrm{C} 21$ [34]. A potential reason for the lack of benefit of $\mathrm{C} 21$ in this study was the fact that the same dose of C21 used successfully as a bolus injection in a MI model in rats $[33 \bullet \cdot]$ was applied in this study as a continuous infusion by minipumps, thus-considering a plasma half-life of $\mathrm{C} 21$ of $4 \mathrm{~h}$-presumably not reaching effective plasma levels. Moreover, the authors themselves discussed that the larger infarct sizes obtained in their study could have masked beneficial effects of $\mathrm{C} 21$.

In a model of hypertension-induced renal dysfunction (salt-loaded SHR-SP), C21 delayed the occurrence of brain damage and reduced proteinuria [29]. These beneficial effects were specifically related to $\mathrm{AT}_{2} \mathrm{R}$ stimulation since they were abolished by PD123319. The authors observed an attenuation of inflammatory and fibrotic processes in the kidneys, pointing again to the anti-inflammatory properties of C21. In a two-kidney-one-clip (2K1C) rat model of hypertension, in which the inflammatory status is upregulated as highlighted by the increase of TNF- $\alpha$ tumor necrosis factor- $\alpha$ ), IL-6 (interleukin 6 ) and TGF- $\beta 1$ expression in the clipped kidneys, C21 significantly decreased these inflammatory markers [26•]. However, these effects were not completely blocked by PD123319. One possible explanation may rely on differences between these two $\mathrm{AT}_{2} \mathrm{R}$ ligands concerning the choice of their administration route or their affinity for $\mathrm{AT}_{2} \mathrm{R}\left[26^{\bullet}\right]$.

These recent studies highlighted that $\mathrm{C} 21$ affords antiinflammatory properties via direct stimulation of $\mathrm{AT}_{2} \mathrm{R}$. Underlying mechanisms were investigated by Rompe et al. [35••]. Human primary dermal fibroblasts were incubated with TNF- $\alpha$ in order to induce IL- 6 expression. C21 treatment decreased IL-6, MCP-1 and TNF- $\alpha$ expressions, thus arguing for its anti-inflammatory action. This effect was also reported in endothelial cells from the human umbilical vein. Pre-incubation of cells with PD123319 abolished this effect, 
providing the evidence that these actions were $\mathrm{AT}_{2} \mathrm{R}$ dependent. The authors further observed that the inhibitory effect of C21 on IL-6 expression was suppressed under inhibition of serine/threonine or tyrosine phosphatases, thus demonstrating that the anti-inflammatory cascade below $\mathrm{AT}_{2} \mathrm{R}$ stimulation implies stimulation of phosphatases. Moreover, the effect of C21 on IL-6 generation was also suppressed when cells were preincubated with a selective inhibitor of arachidonate epoxygenation, indicating that the arachidonic acid metabolite 11,12- epoxyeicosatrienoic acid (EET) constitutes a second messenger in the $\mathrm{AT}_{2} \mathrm{R}$-dependent anti-inflammation pathway. This is in agreement with EET acting as an anti-inflammatory mediator in vascular inflammation [36]. Rompe et al. also investigated whether the changes in IL- 6 expression by $\mathrm{C} 21$ were related to a change in NF- $\mathrm{KB}$ (nuclear factor- $\mathrm{KB}$ ) activity as IL-6 transcription is under the control of this transcription factor. This was achieved by monitoring nuclear translocation of the NF- $\mathrm{KB}$ p50 subunit and also by measuring NF- $\mathrm{kB}-$ dependent IL-6 promoter transcriptional activity via a luciferase reporter assay. C21 indeed reduced NF- $\mathrm{kB}$ activity and translocation. Moreover, in a mouse model of cutaneous inflammation, in which IL-6, MCP-1 and TNF- $\alpha$ mRNA are upregulated, $\mathrm{C} 21$ induced a significant reduction of these inflammatory markers, providing further in vivo evidence of $\mathrm{C} 21$ 's anti-inflammatory properties. Thus, $\mathrm{AT}_{2} \mathrm{R}$-dependent anti-inflammation seems to involve activation of protein phosphatases, epoxidation of arachidonic acid to EETs and inhibition of NF- $\mathrm{KB}$ reducing pro-inflammatory cytokines (Fig. 1) [35••]. It is important to note that, on the IL-6 promoter level, the NF-KB inhibition in this study was comparable in strength to inhibition provided by hydrocortisone, thus supporting the idea that $\mathrm{C} 21$ should be studied as a potential drug candidate in inflammatory diseases $[35 \bullet \cdot$.

Finally, as inflammatory processes also contribute to the pathophysiology of hypertension, their inhibition may potentiate the benefit of blood pressure reduction [37]. The $\mathrm{AT}_{2} \mathrm{R}$ agonist $\mathrm{C} 21$, partly via its anti-inflammatory properties, may thus be the ideal partner of ARBs in the context of hypertension and related cardiovascular complications (Fig. 1).

\section{Perspectives}

Although stimulation of $\mathrm{AT}_{2} \mathrm{R}$ by $\mathrm{C} 21$ seems to generate numerous actions such as anti-apoptosis and anti-fibrosis [33••], several recent studies reviewed above highlight anti-inflammation as a major function of $\mathrm{C} 21$. Therapeutically, C21 could therefore be used as a tool in order to counteract pathologic inflammatory processes. Beyond cardiovascular diseases, in which inflammation is only a part of the pathophysiological process, C21 could enlarge
Fig. 1 Schematic overview of the $\mathrm{AT}_{2} \mathrm{R}$-dependent anti-inflammation signaling pathway, counteracting the proinflammatory action of $\mathrm{AT}_{1} \mathrm{R}$ activation. Due to its anti-inflammatory properties, the $\mathrm{AT}_{2} \mathrm{R}$ agonist $\mathrm{C} 21$ may be the ideal partner of ARBs in the context of hypertension and related cardiovascular complications. C21 could also enlarge its therapeutic perspectives to noncardiovascular inflammatory diseases. Ang II, angiotensin II; $A T_{1} R$, angiotensin II receptor subtype $1 ; A T_{2} R$, angiotensin II receptor subtype $2 ; A R B$, angiotensin receptor blocker; C21, compound 21; CYP, cytochrome $\mathrm{P} 450 ; A A$, arachidonic acid; 11, 12-EET, 11, 12-epoxyeicosatrienoic acid; $N F-k B$, nuclear factor $\mathrm{kB}$

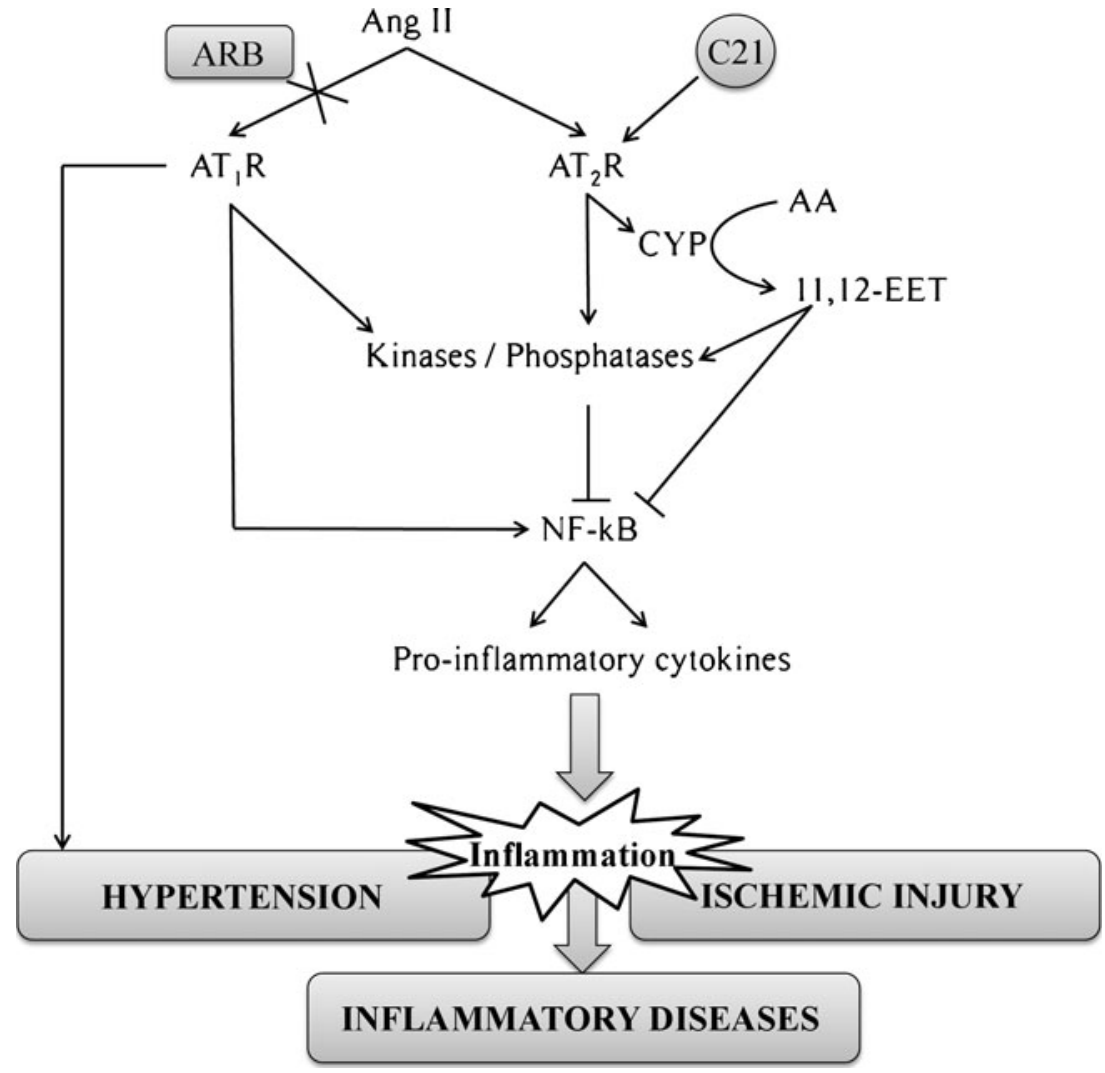


its therapeutic perspectives to non-cardiovascular inflammatory diseases.

Beyond classical treatments, stem cells constitute promising candidates for future therapies [38]. Moreover, there is a growing body of evidence suggesting that RAS, and $\mathrm{AT}_{2} \mathrm{R}$ in particular, are implied in the proliferation and differentiation of hematopoietic and mesenchymal stem cells (see [39-] for review). In their recent review, Durik et al. addressed the impact of RAS modulation, and in particular $\mathrm{AT}_{2} \mathrm{R}$ stimulation, on tissue regeneration by progenitor cells [39•]. Indirect evidence suggests that $\mathrm{AT}_{2} \mathrm{R}$ stimulation may improve the therapeutic effects of MSC grafts in myocardial infarction [40] and brain ischemia [41].

The cellular mechanisms involved in the cardioprotective role of $\mathrm{AT}_{2} \mathrm{R}$ have been further investigated following MI. The expression of $\mathrm{AT}_{2} \mathrm{R}$ has been indeed observed in human cardiac stem cells as well as in CD8-positive $\mathrm{T}$ cells $\left(\mathrm{CD} 8^{+}\right.$ $\mathrm{AT}_{2} \mathrm{R}^{+} \mathrm{T}$ cells) in the peri-infarct area $[42 \bullet \bullet, 43] . \mathrm{AT}_{2} \mathrm{Rs}$ are increased in human cardiac stem cells after MI, and their stimulation with $\mathrm{C} 21$ attenuated apoptosis of cardiomyocytes [43]. Besides, $\mathrm{AT}_{2} \mathrm{Rs}$ are also expressed in a fraction

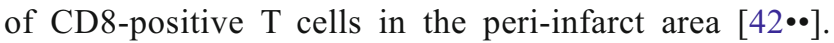
Contrary to $\mathrm{CD} 8^{+} \mathrm{AT}_{2} \mathrm{R}^{-} \mathrm{T}$ cells, $\mathrm{CD}^{+} \mathrm{AT}_{2} \mathrm{R}^{+} \mathrm{T}$ cells did not induce cytotoxicity to cardiomyocytes and exhibited a decreased expression of proinflammatory cytokines. Intramyocardial transplantation of these cells after MI reduced the infarct size, thus providing in vivo evidence of cardioprotection via $\mathrm{CD}^{+} \mathrm{AT}_{2} \mathrm{R}^{+} \mathrm{T}$ cells. These studies highlighted an $\mathrm{AT}_{2} \mathrm{R}$-mediated cellular mechanism protecting the heart from injury at least in part via anti-apoptotic and anti-inflammatory actions. This could contribute to the beneficial effects observed in post-MI following an acute [33••] or a chronic C21 treatment [44].

Otherwise, the neuroprotective action of $\mathrm{AT}_{2} \mathrm{R}$ has in particular been previously investigated after transient cerebral ischemia by unilateral middle cerebral artery occlusion in the rat [19]. In this model, $\mathrm{AT}_{2} \mathrm{Rs}$ were upregulated in neuronal cells of the peri-ischemic area, and this was associated with cerebroprotective actions. In order to explore the underlying mechanisms, the authors focused on the role of $\mathrm{AT}_{2} \mathrm{Rs}$ in primary neuronal cells. They highlighted that $\mathrm{AT}_{2} \mathrm{R}$ stimulation promotes neurite outgrowth and neuronal survival [19]. This may support the $\mathrm{AT}_{2} \mathrm{R}$-dependent neuroprotection provided by MSC grafts during brain ischemia [41]. Stimulation of $\mathrm{AT}_{2} \mathrm{R}$ of progenitor cells seems to improve the effects of cell therapy treatments in the context of cardiovascular and neural injury, acting as a repair system [39•].

\section{Conclusion}

Although the $\mathrm{AT}_{2} \mathrm{R}$ agonist $\mathrm{C} 21$ does not act as a classical antihypertensive drug, it could be useful in preventing hypertension-induced organ damage. Moreover, a body of evidence emerges around its anti-inflammatory feature: this should be further investigated for a potential clinical indication.

Considering the $\mathrm{AT}_{2} \mathrm{R}$ expression levels in healthy (low expression) and injured tissues (upregulated expression), direct $\mathrm{AT}_{2} \mathrm{R}$ stimulation with $\mathrm{C} 21$ could constitute a selective repair therapy directed at the injury site, with a limited occurrence of adverse events. $\mathrm{AT}_{2} \mathrm{R}$ agonists are the first agonists of the RAS developed with a therapeutic goal. Up to now, the therapeutic goal of interfering with the RAS was slowing down the renin/ACE/AT 1 axis. In contrast to this approach, $\mathrm{AT}_{2} \mathrm{R}$ agonists, with the lead compound $\mathrm{C} 21$, may afford new therapeutic options via promotion of the "protective RAS."

Disclosure S. Foulquier: none; U. M. Steckelings: grant and support for travel to meetings for the study or other purposes from Vicore Pharma; T. Unger: stock/stock options from Vicore Pharma.

\section{References}

Papers of particular interest, published recently, have been highlighted as:

- Of importance

-. Of outstanding importance

1. Chiu AT, Herblin WF, McCall DE, et al. Identification of angiotensin II receptor subtypes. Biochem Biophys Res Commun. 1989;165:196-203.

2. Unger T. The angiotensin type 2 receptor: variations on an enigmatic theme. J Hypertens. 1999;17:1775-86.

3. Vincent J-M, Kwan YW, Chan SL, et al. Constrictor and dilator effects of angiotensin II on cerebral arterioles. Stroke. 2005;36:2691-5.

4. Stoll M, Steckelings UM, Paul M, et al. The angiotensin AT2receptor mediates inhibition of cell proliferation in coronary endothelial cells. J Clin Invest. 1995;95:651-7.

5. Meffert S, Stoll M, Steckelings UM, et al. The angiotensin II AT2 receptor inhibits proliferation and promotes differentiation in PC12W cells. Mol Cell Endocrinol. 1996;122:59-67.

6. Steckelings UM, Kaschina E, Unger T. The AT2 receptor-a matter of love and hate. Peptides. 2005;26:1401-9.

7. $\mathrm{Wu} \mathrm{L}$, Iwai M, Li Z, et al. Regulation of inhibitory protein- $\mathrm{kB}$ and monocyte chemoattractant protein-1 by angiotensin II type 2 receptor activated Src homology protein tyrosine phosphatase-1 in fetal vascular smooth muscle cells. Mol Endocrinol. 2004;18:66678.

8. Nouet S, Nahmias C. Signal transduction from the angiotensin II AT2 receptor. Trends Endocrinol Metab. 2000;11:1-6.

9. Wruck CJ, Funke-Kaiser H, Pufe T, et al. Regulation of transport of the angiotensin AT2 receptor by a novel membraneassociated Golgi protein. Arterioscler Thromb Vasc Biol. 2005;25:57-64.

10. - Rodrigues-Ferreira S, Nahmias C: An ATIPical family of angiotensin II AT2 receptor-interacting proteins. Trends Endocrinol Metab. 2010, 21: 684-690. This article reviews recent discoveries 
concerning a family of $A T_{2}$ receptor-interacting proteins involved in the $A T_{2} R$ signaling, regulation and function.

11. Stoll M, Hahn AWA, Jonas U, et al. Identification of a zinc finger homoeodomain enhancer protein after AT(2) receptor stimulation by differential mRNA display. Arterioscler Thromb Vasc Biol. 2002;22:231-7.

12. Senbonmatsu T, Saito T, Landon EJ, et al. A novel angiotensin II type 2 receptor signaling pathway: possible role in cardiac hypertrophy. EMBO J. 2003;22:6471-82.

13. - Funke-Kaiser H, Reinemund J, Steckelings UM, Unger T: Adapter proteins and promoter regulation of the angiotensin AT2 receptor-implications for cardiac pathophysiology. J Renin Angiotensin Aldosterone Syst 2010, 11: 7-17. This article reviews new identified pathways implied in the modulation of signaling, expression and function of $A T_{2} R$, especially via $A T_{2} R$ adapter proteins and heterodimer formation.

14. Gohlke P, Pees C, Unger T. AT2 receptor stimulation increases aortic cyclic GMP in SHRSP by a kinin-dependent mechanism. Hypertension. 1998;31:349-55.

15. Pees C, Unger T, Gohlke P. Effect of angiotensin AT2 receptor stimulation on vascular cyclic GMP production in normotensive Wistar Kyoto rats. Int J Biochem Cell Biol. 2003;35:963-72.

16. Touyz RM, Endemann D, He G, et al. Role of AT2 receptors in angiotensin II-stimulated contraction of small mesenteric arteries in young SHR. Hypertension. 1999;33:366-72.

17. Widdop RE, Vinh A, Henrion D, Jones ES. Vascular angiotensin AT2 receptors in hypertension and ageing. Clin Exp Pharmacol Physiol. 2008;35:386-90.

18. Foulquier S, Dupuis F, Perrin-Sarrado C, et al. High salt intake abolishes AT2-mediated vasodilation of pial arterioles in rats. J Hypertens. 2011;29:1392-9.

19. Li J, Culman J, Hörtnagl H, et al. Angiotensin AT2 receptor protects against cerebral ischemia-induced neuronal injury. FASEB J. 2005;19:617-9.

20. Makino I, Shibata K, Ohgami Y, et al. Transient upregulation of the AT2 receptor mRNA level after global ischemia in the rat brain. Neuropeptides. 1996;30:596-601.

21. Steckelings UM, Paulis L, Unger T, Bader M. Emerging drugs which target the renin-angiotensin-aldosterone system. Expert Opin Emerg Drugs. 2011;16:619-30.

22. Wan Y, Wallinder C, Plouffe B, et al. Design, synthesis, and biological evaluation of the first selective nonpeptide AT2 receptor agonist. J Med Chem. 2004;47:5995-6008.

23. •- Bosnyak S, Welungoda IK, Hallberg A, et al.: Stimulation of angiotensin AT2 receptors by the non-peptide agonist, Compound 21, evokes vasodepressor effects in conscious spontaneously hypertensive rats. Br. J. Pharmacol. 2010, 159: 709-716. This is the first study demonstrating a C21-induced vasorelaxation in vitro that is translated into a vasodepressor response in vivo when combined with a low dose of $A T_{1} R$ blocker.

24. Hilliard LM, Jones ES, Steckelings UM, et al. Sex-specific influence of angiotensin type 2 receptor stimulation on renal function: a novel therapeutic target for hypertension. Hypertension. 2012;59:409-14.

25. Jing F, Mogi M, Sakata A, et al. Direct stimulation of angiotensin II type 2 receptor enhances spatial memory. J Cereb Blood Flow Metab. 2012;32:248-55.

26. Matavelli LC, Huang J, Siragy HM: Angiotensin $\mathrm{AT}_{2}$ receptor stimulation inhibits early renal inflammation in renovascular hypertension. Hypertension 2011, 57: 308-313. This study provides evidence for the anti-inflammatory actions of $\mathrm{C} 21$ in clipped kidney of the Goldblatt hypertension model.

27. - Rehman A, Leibowitz A, Yamamoto N, et al.: Angiotensin Type 2 Receptor Agonist Compound 21 Reduces Vascular Injury and Myocardial Fibrosis in Stroke-Prone Spontaneously Hypertensive Rats. Hypertension 2012, 59: 291-299. This is the first study reporting effects of chronic C21 treatment on the vascular wall in genetic hypertensive rats. C21 reduced the stiffness of mesenteric resistance arteries independently of any blood pressure reduction.

28. - Paulis L, Becker STR, Lucht K, et al.: Direct angiotensin II type 2 receptor stimulation in N $\omega$-nitro-L-arginine-methyl ester-induced hypertension: the effect on pulse wave velocity and aortic remodeling. Hypertension 2012, 59: 485-492. This is the first study reporting the effects of chronic C21 treatment on the vascular wall in a hypertension-induced model. C21 prevented aortic stiffening independently of any blood pressure reduction.

29. Gelosa P, Pignieri A, Fändriks L, et al. Stimulation of AT2 receptor exerts beneficial effects in stroke-prone rats: focus on renal damage. J Hypertens. 2009;27:2444-51.

30. Li XC, Widdop RE. AT2 receptor-mediated vasodilatation is unmasked by AT1 receptor blockade in conscious SHR. Br J Pharmacol. 2004;142:821-30.

31. Barber MN, Sampey DB, Widdop RE. AT(2) receptor stimulation enhances antihypertensive effect of AT(1) receptor antagonist in hypertensive rats. Hypertension. 1999;34:1112-6.

32. Carey RM, Howell NL, Jin XH, Siragy HM. Angiotensin type 2 receptor-mediated hypotension in angiotensin type-1 receptorblocked rats. Hypertension. 2001;38:1272-7.

33. •- Kaschina E, Grzesiak A, Li J, et al.: Angiotensin II type 2 receptor stimulation: a novel option of therapeutic interference with the renin-angiotensin system in myocardial infarction? Circulation 2008, 118: 2523-2532. This is the first in vivo study using C21. A short treatment with C21 improved cardiac function and decreased scar size after myocardial infarction. This was observed in association with a decrease in inflammation and apoptosis markers.

34. Jehle AB, Xu Y, Dimaria JM, et al. A nonpeptide angiotensin II type 2 receptor agonist does not attenuate postmyocardial infarction left ventricular remodeling in mice. J Cardiovasc Pharmacol. 2012;59:363-8

35. • Rompe F, Artuc M, Hallberg A, et al.: Direct angiotensin II type 2 receptor stimulation acts anti-inflammatory through epoxyeicosatrienoic acid and inhibition of nuclear factor kappaB. Hypertension 2010, 55: 924-931. This is the first study showing anti-inflammatory effects of direct $A T_{2} R$ stimulation by $C 21$ in vitro and in vivo. Underlying signaling mechanisms are reported.

36. Node K, Huo Y, Ruan X, et al. Anti-inflammatory properties of cytochrome P450 epoxygenase-derived eicosanoids. Science. 1999;285:1276-9.

37. Savoia C, Schiffrin EL. Inflammation in hypertension. Curr Opin Nephrol Hypertens. 2006;15:152-8.

38. Sánchez PL, Villa A, Sanz R, et al. Present and future of stem cells for cardiovascular therapy. Ann Med. 2007;39:412-27.

39. - Durik M, Sevá Pessôa B, Roks AJM: The renin-angiotensin system, bone marrow and progenitor cells. Clin. Sci. 2012, 123: 205-223. This review addresses the impact of renin-angiotensinsystem modulation on tissue regeneration by progenitor cells. In particular, they highlight the potential importance of $A T_{2} R$ stimulation with agonists in the future of stem cell therapy.

40. Numasawa Y, Kimura T, Miyoshi S, et al. Treatment of human mesenchymal stem cells with angiotensin receptor blocker improved efficiency of cardiomyogenic transdifferentiation and improved cardiac function via angiogenesis. Stem Cells. 2011;29:1405-14.

41. Iwanami J, Mogi M, Li J-M, et al. Deletion of angiotensin II type 2 receptor attenuates protective effects of bone marrow stromal cell treatment on ischemia-reperfusion brain injury in mice. Stroke. 2008;39:2554-9.

42. • Curato C, Slavic S, Dong J, et al.: Identification of noncytotoxic and IL-10-producing CD8 + AT2R + T cell population in response 
to ischemic heart injury. J. Immunol. 2010, 185: 6286-6293. This study revealed the expression of $A T_{2} R$ in $C D 8^{+} T$ cells in the periinfarct myocardium, thus revealing an $A T_{2} R$-mediated cellular mechanism in regulating immune response during ischemic heart injury.

43. Altarche-Xifró W, Curato C, Kaschina E, et al. Cardiac c-kit + AT2 + cell population is increased in response to ischemic injury and supports cardiomyocyte performance. Stem Cells. 2009;27:2488-97.

44. Lauer D, Slavic S, Sommerfeld M, et al. AT2 receptor stimulation improves cardiac function 6 weeks after myocardial infarction in the rat. [Abstract ESH 8 C.03] Presented at the 22nd European Meeting on Hypertension and Cardiovascular Prevention. London, Great Britain, April 26-29, 2012. 